\title{
The Relationship Between Stress and Quality Life of Women Working in the Washing Tape of Magnesite Mine and Home Women
}

\author{
Ev Kadınlarında ve Manyezit Madeninin Yıkama Bandında Çalışan Kadınlarda \\ Stres ve Yaşam Kalitesi Arasındaki ilişki
}

(D) Burcu KÜÇÜKKAYA, iD Hatice KAHYAOĞLU SÜT

Trakya University Faculty of Health Science, Department of Nursing, Division of Women Health and Diseases Nursing, Edirne, Turkey

\section{ABSTRACT}

Objective: To explore the relationship between stress and quality life of women working in the washing tape of magnesite mine and home women.

Methods: This cross-sectional study was conducted in Eskisehir on total of 288 women that working women in the washing tape of magnesite mine ( $n=144$, group 1) and home women who took municipal courses at two townhouses $(n=144$, group 2$)$ completed structured questionnaire form with personeal features and work status, World Health Organization Short Form of Life- Turkish Version (WHOQOL-BREF-TR) and Depression-Anxiety-Stress scale (DASS-21).

Results: There was a statistically significant difference between physical, psychological, social and environmental dimensions that are sub-dimensions of WHOQOL-BREF-TR between groups and depression, anxiety and stress which are sub-dimensions of DAS-21 Short Form of groups. There was a correlation between physical, psychological, social and environmental sub-dimensions of WHOQOL-BREF-TR and a stress sub-dimensions score of DAS-21 Short Form of group 1 and 2.

Conclusion: While the quality of life of the women working in the washing band of magnesite mine was determined lower than the housewives, the stress status was higher.

Keywords: Home women, magnesite mining, Quality of life, stress, working women
ÖZ

Amaç: Bu çalışmada, ev kadınlarında ve manyezit madeninin yıkama bandında çalışan kadınlarda stres ve yaşam kalitesi arasındaki ilişkinin incelenmesi amaçlanmıştır.

Yöntemler: Kesitsel özellikteki bu araştırma Mayıs-Aralık 2018 tarihleri arasında Eskişehir'de bulunan bir manyezit madeninin yıkama bandında çalışan n=144 kadın (grup 1), Eskişehir'de bir belediyeye bağlı iki belde evinde kurs alan ve ev kadını olan $n=144$ kadın (grup 2) toplamda n=288 kadın üzerinde yürütülmüştür. Veriler anket formu, Dünya Sağlık Örgütü Yaşam Kalitesi Kısa Formu-Türkçe Versiyon (WHOQOLBREF-TR) ve Depresyon- Anksiyete- Stres Ölçeği Kısa Formu (DASS21) ile toplanmıştır.

Bulgular: Gruplar arasinda DASS-21 Kisa Form alt boyut ve toplam puanları ile WHOQOL-BREF-TR alt boyut puan ortalamaları açısından istatistiksel olarak anlamlı farklılık belirlenmiştir. Grup 2'nin WHOQOL-BREF-TR'nin alt boyutları olan bedensel, ruhsal, sosyal ilişkiler ve çevre boyutları ile DAS-21 Kısa Formu'nun alt boyutları olan depresyon, anksiyete ve stres arasinda ve WHOQOL-BREF-TR'nin alt boyutları olan bedensel ile ruhsal boyutları ve DAS-21 Kisa Formu toplam puanı arasında istatistiksel olarak anlamlı farklılık saptanmıştır. Grup 1'in WHOQOL-BREF-TR'nin alt boyutları olan bedensel, ruhsal, sosyal ilişkiler ve çevre boyutları ile DAS-21 Kısa Formu'nun toplam ve alt boyutları olan depresyon, anksiyete ve stres arasında istatistiksel olarak anlamlı farklılık bulunmuştur.

Sonuç: Manyezit madeninin yıkama bandında çalışan kadınların yaşam kalitesi ev kadınlarına göre daha düşük ve stres durumu daha yüksek bulundu.

Anahtar Sözcükler: Ev kadını, manyezit madeni, çalışan kadın, stres, yaşam kalitesi
Address for Correspondence: Burcu KÜÇÜKKAYA, Trakya University Faculty of Health Science, Department of Nursing, Division of Women Health and Diseases Nursing, Edirne, Turkey

E-mail: burcukucukkaya1992@gmail.com ORCID ID: orcid.org/0000-0002-3421-9794

Cite this article as: Küçükkaya B, Kahyaoğlu Süt H. The Relationship Between Stress and Quality Life of Women Working in the Washing Tape of Magnesite Mine and Home Women. Bezmialem Science 2021;9(2):140-7.

${ }^{\circ}$ Copyright 2021 by the Bezmiâlem Vakıf University

Bezmiâlem Science published by Galenos Publishing House.
Received: 23.01 .2020

Accepted: 05.03.2020 


\section{Introduction}

According to the Turkey Statistical Institute, $49.8 \%$ of the population of Turkey was female as of 2017. This proportional balance between women and men varies in favor of women in the age group of 65 and over because of the longer life expectancy of women: $44 \%$ of the population in this age group is male and $56.0 \%$ is female (1). Women who cannot participate in the workforce because they are caring for their family members and performing housework are working in re-production on behalf of society (2).

As the position of women in society for centuries has bent consistently in favor of that of men, women are battling to find their place in the world today and forever. Women have the tremendous privilege of entering recreation in the progression of any nation. Because the existing intellectual and physical contact of women is much long-lasting and common. However, in connection with women's reproductive and hormonal cycles, the indicators of depression and anxiety are extremely sensitive. Given the situation resulting from the biological and physiological differences between the sexes, working conditions are thought to have a positive effect on women's employment $(3,4)$.

Magnesite, a precious metal that contains magnesium in its composition, has both a very thick and a highly pure composition. These formations are in the form of metamorphic carbonates, varying in color and thickness, while they spread variably according to the metamorphic generations in which they are located (3). Magnesite contains $\mathrm{MgO}$ and $\mathrm{CaO}$, and geochemical analyses are carried out to determine the proportion of the elements therein $(3,5)$. In a magnesite mine, qualitative changes in the structure of unhealthy factors occur in the working environment with the formation of significant changes in raw material extraction technology characterized by a permanent tendency to increase in the magnesite is composed mechanism. These changes can be listed as dust, noise, microclimate, and changes in the working air (6). In this respect, the exposure status to these changes in women working in the magnesite mine varies $v i s-\grave{a}$-vis those of men.

Quality of life is defined by the World Health Organization (WHO) as an individual's own perceptions in the system of culture and values in their own life $(7,8)$. Quality of life is not only a personal health situation but also a broader concept that includes personal well-being $(8,9)$. The health and well-being of women working on the washing band of a magnesite mine are affected to different degrees in terms of physical, mental, social, and environmental aspects. The traditional indicators used to measure health today (illness, death, life expectancy, etc.) are taken into consideration when determining the affected situations and areas. Due to the inadequacy of definition of individuals' health levels, clarification of the issue from the perspective of quality of life is attempted (6). In this context, stress is one of the most important factors affecting quality of life. Stress is basically a physiological condition and progresses as a process (10). Stress is seen as a relationship between the person and the environment. All internal and external stimuli can be a source of stress. In general, human beings have roles in adaptation to physiological and psychological conditions. Therefore, the important point is the level of stress (11). Studies have shown that when stress is significantly complicated, it is primarily caused by physical diseases such as cardiovascular diseases as well as psychiatric disorders such as depressive disorders and anxiety disorders (12-15). Women working on the washing band of a magnesite mine are exposed to more magnesium individual need by both respiration and contact, compared with homemakers. Magnesite mine workers are exposed to factors that affect their physical and mental health more than individuals who are housewives and have handicrafts in their social life. Therefore, it is important for nurses specializing in women's health and disease to apply nursing care individually and appropriate to the needs of both housewives and women working on the washing band of magnesite mines.

Although it is thought that males work mostly in mines in our country and around the world, women work mostly on the washing band of mines. An examination of the literature did not find a relationship between stress levels and quality of life of mineral workers. In this study on the stress and quality of life of women working on the washing band of magnesite mines, compared with that of housewives, the relationship between stress and quality of life in women will be revealed.

\section{Methods}

\section{Study Design}

This cross-sectional type study aimed to investigate the relationship between stress and quality of life in women working on the washing tape of a magnesite mine (group 1) and homemakers (group 2). The study was conducted between May and December 2018 in the Tunalı and Esentepe Townhouses of the Eskişehir Tepebaşı Municipality with a magnesite mining company located in Eskişehir.

\section{Research Questions}

R.Q.1. Is there a difference is stress between the groups?

R.Q.2. Is there a difference in quality of life and its subdimensions between the groups?

\section{Conceptual Framework}

In Turkey and around the world, although there is no clear data on the number of women working in mines, it is believed that fewer women than men work in mines. For this reason, it is determined that the study will be carried out in a magnesite mine because it contains $\mathrm{Mg}$, which represents the universe, has a real effect on women's health, both through respiratory exposure and contact when passing through in the mine, and is used in medical treatments. Required written permission for the study was obtained from the magnesite mining company designated for the study. In addition, townhouses are regionally qualified course areas that support the development of individuals through a variety of educational programs, have permission from government agencies, and have a specific vision and mission, which is based on lifelong learning. 


\section{Participants}

The required sample number was calculated as sufficient to test the two-way hypothesis, with a significance level of $\alpha=0.05$, a power of 0.95 , and an effect size of 0.75 . The effect sample size was verified by the study on quality of life among married working women and housewives by Ahmad and Khan (16). The number of samples calculated for each group was 140 in the present study. However, 144 women each group were included as a precaution against possible missing data. The whole sample was divided into two groups by online computer randomization software (17).

The criteria for inclusion in group 1 were as follows: (1) employment in a magnesite mining company located in Eskişehir; (2) age over 18 years and consent given to participate in the study; (3) presence in a magnesite mining company located in Eskişehir during the study period and; and (4) comprehension of the questions of questionnaire form and scales and ability to without problems. The criteria for inclusion in group 2 were as follows: (1) occupation as a homemaker; (2) age over 18 years; (3) consent given to participate in the study; (4) enrollment in courses in Tunalı and Esentepe Townhouses connected to Eskişehir Tepebaşı Municipality during the study period; and (5) comprehension of the questions on the questionnaire form and scales and ability to communicate without problems.

\section{Data Collection}

A notice on a bulletin board in the magnesite mining company in Eskişehir, Eskişehir Tepebaşı Municipality, and Tunalı and Esentepe Townhouses was used to recruit participants during the recruitment period from May to December 2018. During the research, the researcher confirmed that participants were eligible to be on the participant list. If they were on the list, the researcher explained the study in detail, and participants agreed and provided oral informed consent. The survey took approximately 30 minutes to complete.

\section{Ethical Approval}

To preserve the rights of the participants in the present study, this study was conducted after ethical committee approval was obtained from the Committee for Evaluation of Scientific Research of Trakya University, Faculty of Medicine (BAEK 2018/214), the magnesite mining company in Eskişehir, Eskişehir Tepebasi Municipality, and Tunalı and Esentepe Townhouses gave written permission. Each participant gave oral consent after receiving an explanation of the study goals, questionnaire form, and scales.

\section{Measures}

Questionnaire Form: The literature prepared by the researchers consisted of a total of 25 questions that included personal characteristics (gender, educational status, employment status, income level, place of residence, smoking status, use of alcohol, physical activity/exercise status, marital status, spouse; age, educational status, employment status, duration of marriage, type of family, being satisfied with life, how he felt about himself recently, condition, and duration of discomfort), 18 questions about features of their work (daily working hours, weekly working hours, working conditions, working conditions in a safe environment, satisfaction with working conditions, inclusion in work area, frequent pressure, and stressful situations at work), and seven other questions (18-23).

\section{World Health Organization Quality of Life Brief Form- Turkish (WHOQOL-BREF-TR)}

The WHOQOL-BREF-TR is an instrument developed by the WHO that allows subjective assessment of quality of life (9). The validity and reliability of the WHOQOL-BREF-TR, composed of 26 questions, were tested in 1999 by Eser et al. (23). The WHOQOL-BREF-TR is spread across four domains, including physical health, psychological health, and social and environmental relationships. The physical domain focuses on the capability of performing daily activities, medicines and treatment compliance, liveliness, pain, inconvenience, sleep, rest, and fatigue. The psychological domain evaluates positive and negative feelings, self-esteem, body image, personal beliefs, and interest. The social relationships domain measures relations with other individuals, friendship, social support, and sex life. Finally, the environmental domain includes questions concerning the domestic environment, physical security and safety, economic status, procurement of healthcare services, opportunities for leisure activities, and the physical environment. The questionnaire is scored from 1 to 5 , and each domain score can range between 4 and 20 (as in this study) or between 0 and 100. An overall score is not calculated, and higher score indicates a better QoL (9). In the present study, Cronbach's coefficients of total, physical, psychological, social, and environmental subdimensions of the WHOQOL-BREF-TR were 0.96, 0.95, 0.89, 0.93 , and 0.92 , respectively.

\section{Depression Stress and Anxiety Scale Short Form (DASS-21 Short Form)}

The long form was developed by Lovibond and Lovibond in 1995. The short form of the scale was written by Henry and Crawford in 2005 and by Mahmoud et al. (26) in 2010 and is taken from studies conducted by Yilmaz et al. (27) in 2017. The reliability and validity of the Turkish version were determined $(24,25)$. The DASS-21 Short Form is very well-known tool consisting of 21 symptoms divided into 3 subscales (depression, anxiety, and stress) of 7 items each and has excellent reliability estimates. The scores obtained from each of the dimensions depression, anxiety, and stress indicates that the individual is uncomfortable with the problem. There are no negative elements of the scale, the score on each sub-dimension is between 0 and 21 , and the total score is 63 (27). For stress, a score between 0 and 7 is normal, a score between 7.01 and 9 is light, between 9.01 and 12.5 is medium, one point forward between 12.51 and 16.5 and one point forward between 16.51 and above are considered stress at very advanced levels $(13,28)$. In the present study, Cronbach's coefficients of total, depression, stress, and anxiety domains of the DASS were $0.99,0.99,0.98$, and 0.99 , respectively. 


\section{Data Analyses}

Descriptive statistics, independent $\mathrm{t}$-tests, and chi-square tests were used to identify the homogeneity of participants' characteristics and outcome baseline variables between groups. The chi-square test was used for the comparison of categorical data between the groups. The Student's t-test was used to compare the changes between the groups after calculating the changes in mean scores on the WHOQOL-BREF-TR and DASS-21 Short Form. Pearson's Correlation was used for the relationship between the WHOQOL-BREF-TR and DASS-21 Short Form fort the purpose of the study. A value of $\mathrm{p}<0.05$ was accepted as the threshold for statistical significance. In the data analysis, SPSS 23.0 statistical software (IBM Corp. Released 2011, IBM SPSS Statistics for Windows, Version 20.0 Armonk, NY: IBM Corp.) was used.

\section{Results}

Table 1 and Table 2 present descriptive statistics for general characteristics and work conditions, as well as a comparison of the results of the DASS-21 Short Form and WHOQOL-BREF-TR and the differences between the respective groups. The average ages were 42.1 years [standard deviation $(\mathrm{SD})=7.0$; group 1 )] and 41.9 years $(S D=6.3$; group 2$)$. There existed no statistically significant differences between the two groups in terms of age, spouse's age, duration of marriage (years), education, income status, family type, and working status of spouse. There existed a statistically significant difference between the two groups in terms satisfaction with life and the feeling recently more (Table 1). Table 2 reveals that the mean stress level of group 1 was 18.57 (SD =5.67) in contrast to $4.55(\mathrm{SD}=5.36)$ for that of group 2 . The difference was statistically significant $(\mathrm{t}=21.57$, $\mathrm{p}=0<0.001$ ), which was a significant difference in the average of the total and sub-dimension score on the DASS-21 Short Form of the two groups. Moreover, the mean of the physical, psychological, social, and environmental sub-dimensions of the WHOQOL-BREF-TR was $13.32(\mathrm{SD}=2.03), 12.68(\mathrm{SD}=2.53)$, $10.58(\mathrm{SD}=4.24)$, and $11.07(\mathrm{SD}=2.85)$ in group 1 , respectively, and $16.43(\mathrm{SD}=2.31), 17.72(\mathrm{SD}=2.79), 17.78(\mathrm{SD}=3.38)$, and $16.99(\mathrm{SD}=2.89)$ in group 2 , respectively. The difference was statistically significant $(t=-12.14, p=0<0.001 ; t=-16.06$, $\mathrm{p}=0<0.001 ; \mathrm{t}=-15.94, \mathrm{p}=0<0.001 ;$ and $\mathrm{t}=-17.45, \mathrm{p}=0<0.001$, respectively), which was a significant difference in the average of physical, psychological, social, and environmental sub-dimension scores of the WHOQOL-BREF-TR of the two groups.

Table 3 shows the correlation between the WHOQOLBREF-TR and DASS-21 Short Form in both groups. There was a correlation between the average scores on the physical, psychological, social, and environmental sub-dimensions of the WHOQOL-BREF-TR and the average total scores on the DASS-21 and the depression, anxiety, and stress sub-dimensions of the DASS-21 in group $1(\mathrm{p}<0.001)$. There was a correlation between the average scores on the physical, psychological, social, and environmental sub-dimensions of the WHOQOL-BREFTR and the average total score on the DASS- 21 and on the depression, anxiety, and stress sub-dimensions of the DASS-21 in homemakers $(\mathrm{p}<0.001)$ (Table 3$)$.

\section{Research Question Testing}

R.Q.1. It was found that group 1 perceived their stress level to be 14.03 points higher than that of group $2(\mathrm{p}<0.001)$. Thus, this hypothesis was supported, as shown in Table 2.

R.Q.2. It was found that the level of physical, psychological, social, and environmental sub-dimensions of quality of life in group 1 were, respectively, 3.11, 5.04, 7.19, and 5.92 points lower than those of group $2(\mathrm{p}<0.001)$. Thus, this hypothesis was supported, as shown in Table 2.

\section{Discussion}

To our knowledge, this was the first study comparing perceived stress and QoL in women working in on the washing band of a magnesite mine and homemakers. The findings contribute to the evidence that managing the stresses of working conditions and improving quality of life can play a significant direct role in decreasing the negative effect of perceived stress on QoL and that identifying working conditions and recent feelings may be a major priority to improve QoL in women working on the washing band of magnesite mines.

In the study, it was determined that women working on the washing band of a magnesite mine experienced more stress than homemakers (Table 2). The study of Abbas et al. (29), which examined social support for the stress of working and nonworking women in Pakistan, reported that working women experienced more stress than non-working women. Studies of Rathod (30) reported that working women have higher stress levels than non-working women. The study by Sharma and Mishra (31) reported that while work, children, and household tasks are the most common stress factors in working women, children, articles and stress constructors are the stress factors in non-working women, and working women have higher stress levels compared with non-working women. Studies of Shukla et al. (32) reported that working women have higher stress levels than non-working women. In the study of Patil (33), which examined the stress levels of working and non-working women, it was reported that working women experienced more stress than non-working women. A study by Anindita and Vijaya (34), which examined the relationship between working and non-working women's modernization status and stress, included 100 women and 100 non-working women. They found that working and non-working women differed significantly in terms of modernization, and employees had higher scores on the stress scale than those who did not work (34). In contrast to our study, the study of Arslan and Ceviz (35), in which housewives and working women evaluated the prevalence of obesity and healthy lifestyle behaviors, did not find a significant difference between housewives and working women in terms of stress management. Since the stress level of working women was higher than that of non-working women, our study findings show parallelism with the literature. Due to the difficult working conditions of women 
Table 1. The general characteristics and working conditions of the two study groups

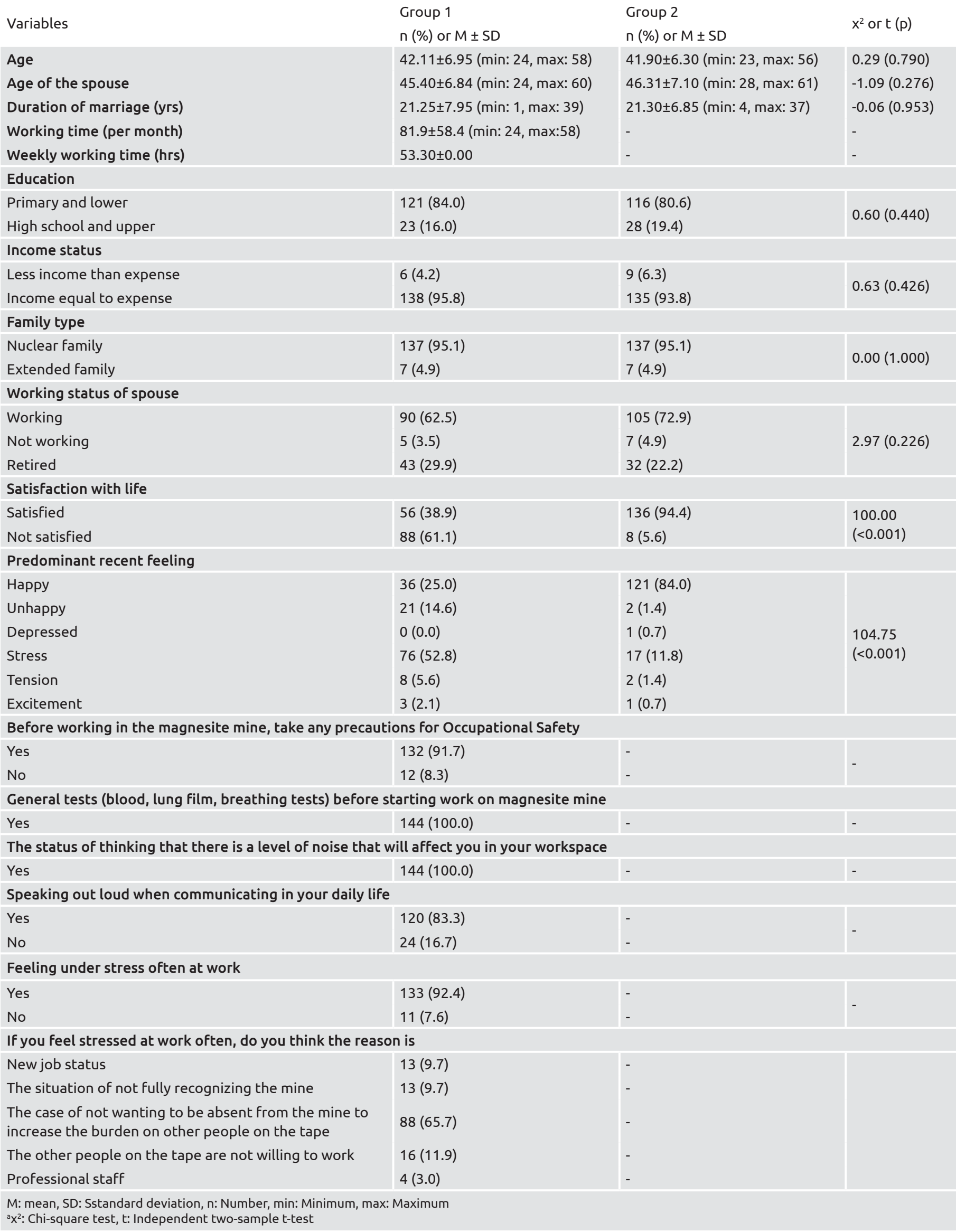


working in magnesite mines, people in social and business life can be said to experience more stress than those at home.

In this study, it was determined that the quality of life of homemakers was higher than that of working women on the washing band of a magnesite mine (Table 2). A study by of Ahmad and Khan (16) that examined the quality of life of married women who were working and housewives reported that the quality of life of working women was lower in terms of social and environmental relations. Research has shown a significant difference between working women and homemakers in terms of physical, mental, social, and environmental quality of life (36). In contrast to our study, that of Bhattacharya and Ganguli (37) examined attitudes toward money, material value, and quality of life expressed by working and non-working women, and there was no significant difference in quality of life between working and non-working women. A study by Mukerji and Sharma (38) indicated that the quality of life of working women was higher than that of non-working women because of having a motivating job, feeling safe, feeling confident and satisfied with it, and feeling close to other people who exist in individual lives. Our study findings and the literature showed that the quality of life of housewives is higher than that of working women.
In the study, it was found that the quality of physical, mental, social, and environmental life decreased as depression, anxiety, and stress levels both of working women on the washing band of a magnesite mine and of homemakers increased (Table 3). A study by Rusli et al. (39) has showed that stress in working women is directly related to anxiety and depression, physical and social relationships, and decreased environmental quality of life. It can be said in this direction that stress levels in both working women and homemakers are thought to have a negative effect on quality of life by increasing anxiety and depression.

\section{Study Limitations}

With regard to the limitations of this research, this study used a cross-sectional design specific to the targeted participants only. This study focused on assessing the time duration for the development of stress and quality of life among women working on the washing band of a magnesite mine and homemakers. Moreover, it is advisable to test other scales to calculate working stress and health issues in working women in various mining organizations in Turkey. The researchers collected data from women working on the washing tape of the magnesite mine for the current research sample; therefore, the results cannot be generalized to women working in other mines. Thus, for

Table 2. Comparison and results of the DASS-21 Short Form And WHOQOL-BREF-TR between groups

\begin{tabular}{|c|c|c|c|c|c|}
\hline \multicolumn{2}{|l|}{$\begin{array}{l}\text { Variables } \\
M \pm S D\end{array}$} & $\begin{array}{l}\text { Group } 1 \\
M \pm S D\end{array}$ & Group 2 & Differences & $t(p)$ \\
\hline \multirow{4}{*}{$\begin{array}{l}\text { DASS-21 } \\
\text { short form }\end{array}$} & Depression & $16.00 \pm 6.62$ & $0.73 \pm 2.68$ & $15.27 \pm 0.60$ & $25.65(<0.001)$ \\
\hline & Anxiety & $15.75 \pm 6.96$ & $1.53 \pm 3.27$ & $14.23 \pm 0.64$ & $22.17(<0.001)$ \\
\hline & Stress & $18.57 \pm 5.67$ & $4.55 \pm 5.36$ & $14.03 \pm 0.65$ & $21.57(<0.001)$ \\
\hline & Total & $50.48 \pm 18.18$ & $6.81 \pm 9.55$ & $43.67 \pm 1.71$ & $25.48(<0.001)$ \\
\hline \multirow{4}{*}{$\begin{array}{l}\text { WHOQOL } \\
\text {-BREF-TR }\end{array}$} & Physical & $13.32 \pm 2.03$ & $16.43 \pm 2.31$ & $-3.11 \pm 0.26$ & $-12.14(<0.001)$ \\
\hline & Psychological & $12.68 \pm 2.53$ & $17.72 \pm 2.79$ & $-5.04 \pm 0.31$ & $-16.06(<0.001)$ \\
\hline & Social & $10.58 \pm 4.24$ & $17.78 \pm 3.38$ & $-7,19 \pm 0.45$ & $-15.94(<0.001)$ \\
\hline & Environmental & $11.07 \pm 2.85$ & $16.99 \pm 2.89$ & $-5.92 \pm 0.34$ & $-17.45(<0.001)$ \\
\hline
\end{tabular}

WHOQOL-BREF-TR: World Health Organization Short Form of Life- Turkish Version, DASS-21: Depression-Anxiety-Stress Scale, M: Mean, SD: Standard deviation, at:Independent two-sample t-test

Table 3. Correlation between the WHOQOL-BREF-TR and DASS-21 short form between groups

\begin{tabular}{|c|c|c|c|c|c|}
\hline \multicolumn{2}{|l|}{ Variables } & \multicolumn{4}{|l|}{ Group 1} \\
\hline \multirow{2}{*}{\multicolumn{2}{|c|}{$\begin{array}{l}\text { DASS-21 short form } \\
\text { Physical }\end{array}$}} & \multicolumn{4}{|c|}{ WHOQOL-BREF-TR } \\
\hline & & Psycholo-gical & Social & Environmental & Physical \\
\hline Depression & $\begin{array}{l}\mathrm{p} \\
\mathrm{p}\end{array}$ & $\begin{array}{l}-0.38 \\
<0.001\end{array}$ & $\begin{array}{l}-0.51 \\
<0.001\end{array}$ & $\begin{array}{l}-0.22 \\
0.010\end{array}$ & $\begin{array}{l}-0.45 \\
<0.001\end{array}$ \\
\hline Anxiety & $\begin{array}{l}p \\
p\end{array}$ & $\begin{array}{l}-0.35 \\
<0.001\end{array}$ & $\begin{array}{l}-0.50 \\
<0.001\end{array}$ & $\begin{array}{l}-0.25 \\
0.003\end{array}$ & $\begin{array}{l}-0.43 \\
<0.001\end{array}$ \\
\hline Stress & $\begin{array}{l}b \\
b\end{array}$ & $\begin{array}{l}-0.46 \\
<0.001\end{array}$ & $\begin{array}{l}-0.72 \\
<0.001\end{array}$ & $\begin{array}{l}-0.50 \\
<0.001\end{array}$ & $\begin{array}{l}-0.73 \\
<0.001\end{array}$ \\
\hline Total & $\begin{array}{l}p \\
p\end{array}$ & $\begin{array}{l}-0.42 \\
\leq 0.001\end{array}$ & $\begin{array}{l}-0.61 \\
0.004\end{array}$ & $\begin{array}{l}-0.34 \\
0.263\end{array}$ & $\begin{array}{l}-0.56 \\
0.128\end{array}$ \\
\hline
\end{tabular}

Group 2

\begin{tabular}{|c|c|c|c|}
\hline \multicolumn{4}{|c|}{ WHOQOL-BREF-TR } \\
\hline Psycholo-gical & Social & Environmental & \\
\hline-0.67 & -0.57 & -0.63 & -0.60 \\
\hline$<0.001$ & $<0.001$ & $<0.001$ & $<0.001$ \\
\hline-0.67 & -0.59 & -0.64 & -0.43 \\
\hline$<0.001$ & $<0.001$ & $<0.001$ & $<0.001$ \\
\hline-0.69 & -0.75 & -0.71 & -0.75 \\
\hline$<0.001$ & $<0.001$ & $<0.001$ & $<0.001$ \\
\hline-0.80 & -0.79 & -0.79 & -0.80 \\
\hline$<0.001$ & $<0.001$ & $<0.001$ & $<0.001$ \\
\hline
\end{tabular}

WHOQOL-BREF-TR: World Health Organization Short Form of Life- Turkish Version, 
future research, we suggest that, in order to evaluate the effect of magnesite mining on quality of life and stress, it is compared with working women in the same institution but who are not in charge of the mine washing band, and descriptive or experimental techniques should be used to investigate the coping mechanisms of working women in the magnesite mine to measure mental, physical, and psychological health issues. Hence, large samples are advisable for a more extensive assessment of magnesite mining workers and non-working women.

\section{Conclusion}

In the study, women working on the washing band of a magnesite mine experienced more stress than homemakers; the quality of life of homemakers was higher than that of working women on the washing band of a magnesite mine; it was determined that both women working on the washing band of a magnesite mine and homemakers experienced increased depression, anxiety, and stress levels, as their physical, mental, social, and environmental quality of life decreased.

According to the findings, we recommend that working conditions should be improved for women working on the washing band of magnesite mines to reduce their stress levels and improve their quality of life, that homemakers have more time allocated to themselves, and that women should take advantage of courses and activities in a shorter time frame so that working women may obtain quality, stress-reducing efforts; moreover, women's health and disease nurses should organize education programs on methods of coping with stress and improving quality of life with a holistic approach to both women working on the washing band of magnesite mines and homemakers, conduct seminars and practices on complementary and alternative treatment methods for coping with stress, and provide follow-up of individuals with tele-nursing practices.

\section{Acknowledgment}

We thank for Turkey Tunalı and Esentepe Townhouses connected to Eskişehir Tepebaşı Municipality in Eskişehir, Turkey for his provision to our study and his support for our connection with homemakers.

\section{Ethics}

Ethics Committee Approval: To preserve the rights of the participants in the present study, this study was conducted after ethical committee approval was obtained from the Committee for Evaluation of Scientific Research of Trakya University, Faculty of Medicine (BAEK 2018/214).

Informed Consent: Obtained.

Peer-review: Externally peer reviewed.

\section{Authorship Contributions}

Concept: B.K., H.K.S., Design: B.K., H.K.S., Data Collection or Processing: B.K., H.K.S., Analysis or Interpretation: B.K., H.K.S., Literature Search: B.K., H.K.S., Writing: B.K., H.K.S.
Conflict of Interest: No conflict of interest was declared by the authors.

Financial Disclosure: The authors declared that this study received no financial support.

\section{References}

1. Turkey statistical institute (TSI). Population and demography. 2017 [cited 2018 Aug 15]. Available from: https://biruni.tuik.gov. tr/medas $/$ kn=95\&locale=trWorld Health Statistics. (2015). World Health Organization 2015.

2. Dibaji SM, Oreyzi SHR, Abedi MR. Occupation or Home: Comparison Housewives and Working Women in the Variables of Stress, Depression and Perception of Quantitative, Mental and Emotional Home Demands. Review of European Studies 2017;9:268-74.

3. Al-Mashaikie SZA. MA'RIB Bölgesi'nde (Arabistan Yarımadası gb'sı) ilk keşfedilen manyezitdolomit kuşağının kökeni, sedimantolojisi ve mineralojisi. Maden Teknik Arama Dergisi 2017;154:111-35.

4. Zaidi SMIH, Lemberg K, Azeem S. Anxiety, Stress and Demographic Predictors of Depression among Adult Working Women. Anxiety 2015;1:68-75.

5. Spadafora A, Perri E, Mckenzie JA, Vasconcelos CG. Microbial biomineralization processes forming modern $\mathrm{Ca}: \mathrm{Mg}$ carbonate stromatolites. Sedimentology 2010;57:27-40.

6. Roda S, Fabianová E, Gajdosová D, Gajdos O, Vidová P. Monitoring and evaluating the effect of the working environment factors on health of staff in the magnesite mine in Slovak Republic. Boletim Paranaense de Geociências 2002;50:105-117.

7. Kilinc H, Bayrakdar A, Celik B, Mollaogulları H, Gencer YG. Physical activity level and quality of life of university students. Journal of Human Sciences 2016;13:3794-3806.

8. World Health Statistics. Global health indicators. World Health Organization 2015;1-122.

9. What Quality of Life Assessment Group.(1996). What Quality of Life/ The WHOQOL Group. World Health Forum 1996;17:354-6.

10. Scott SB, Graham-Engeland JE, Engeland CG, Smyth JM, Almeida DM, Katz MJ, et al. The Effects of Stress on Cognitive Aging, Physiology and Emotion (ESCAPE) Project. BMC Psychiatry 2015;15:146.

11. Ozkaya MO, Yakin V, Ekinci T. Effect of stress levels upon the job satisfaction of the employess an emprical study on employees of Celal Bayar University. Management and Economics 2008;15:163-80.

12. Nur Azma BA, Rusli BN, Quek KF, Noah RM. Psychometric properties of the Malay version of the Depression Anxiety Stress Scale-21 (M-DASS21) among nurses in public hospitals in the Klang Valley. International Journal of Collaborative Research on Internal Medicine \& Public Health 2014;6:109-20.

13. Hekimoglu L, Altun ZO, Kaya EZ, Bayram N, Bilgel N. Psychometric properties of the Turkish version of the 42 item Depression Anxiety Stress Scale (DASS-42) in a clinical sample. Int J Psychiatry Med 2012;44:183-98.

14. Cicek CG. The relationship between stress level and job satisfaction of seafarers: A research in a maritime company. Master Thesis. Manisa Celal Bayar University 2006. 
15. Abid R, Saleem N, Khalid HA, Ahmad F, Rizwan M, Manzoor J, et al. Stress Detection of the Employees Working in Software Houses using Fuzzy Inference. International Journal of Advanced Computer and Applications 2019;10:217-24.

16. Ahmad M, Khan A. Quality of Life Among Married Working Women and Housewives. International Journal of Engineering \& Technology Singaporean Journal of Social Science 2018:13-18.

17. Randomization.com. http://www.randomization.com/, (Retrived to 12.06.2018).

18. Senol Y, Daloglu M, Baysal OD, Gurpinar E. Evaluation of the quality of life and general health of medical residents. Indian J of Med Spec 2018;9:7-11.

19. Saricam H. The Psychometric Properties of Turkish Version of Depression Anxiety Stress Scale-21 (DASS-21) in Health Control and Clinical Samples. Journal of Cognitive Behavioral Psychotherapy and Research 2018;7:19-30.

20. Easton S, Van Laar D. User manual for the Work-Related Quality of Life (WRQoL) Scale: a measure of quality of working life. University of Portsmouth Ageing Network.; 2018.

21. Dilek B, Korkmaz F, Bas G, Deniz B, Yılmaz N, Dogan S, ve ark. Evaluation of Musculoskeletal Problems and Quality of Life in Physicians who Working in a University Hospital. Journal of Medical Faculty of Dokuz Eylul University 2016;30:25-30.

22. Altiparmak S, Eser E. The Quality of Life in 15-49 Years Old Married Women. Journal of Social Policy Studies 2007;11:29-33.

23. Eser E, Fidnner H, Fidaner C, Eser SY, Elbi H, Göker E.Psychometric properties of the WHOQOL-100 and WHOQOL-BREF. 3P DERGİSİ 1999;7:5-13.

24. Henry JD, Crawford JR. The short-form version of the Depression Anxiety Stress Scales (DASS-21): construct validity and normative data in a large non-clinical sample. Br J Clin Psychol 2005;44:22739.

25. Lovibond PF, Lovibond SH. The structure of negative emotional states: comparison of the Depression Anxiety Stress Scales (DASS) with the Beck Depression and Anxiety Inventories. Behav Res Ther 1995;33:335-43.

26. Mahmoud JS, Staten R, Hall LA, Lennie TA. The relationship among young adult college students' depression, anxiety, stress, demographics, life satisfaction, and coping styles. Issues Ment Health Nurs 2012;33:149-56.
27. Yilmaz Ö, Boz H, Arslan A. The validity and reliability of Depression Stress and Anxiety Scale (DASS-21) Turkish Short Form. Journal of Economics and Social Research 2017;2:78-91.

28. The Depression, Anxiety and Stress Scale-21 Items (DASS-21) Scoring.

29. Abbas J, Aqeel M, Abbas J, Shaher B, A J, Sundas J, et al. The moderating role of social support for marital adjustment, depression, anxiety, and stress: Evidence from Pakistani working and nonworking women. J Affect Disord 2019;244:231-8.

30. Rathod SK. A study of the level of life-stress of working and nonworking women. Research Journey- International E- Research Journal 2019;121:57-64.

31. Sharma K, Mishra S. Comparative study of well-being of working and non-working women. Indian Journal of Health and Wellbeing 2018;9:799-801.

32. Shukla S, Jaiswal M, Agrahari K, Shingh A. A study on stress level among working and non-working women. IJHS 2017;3:349-357.

33. Patil M. Stress level of working and non working women. The International Journal of Indian Psychology 2016;3:31-37.

34. Anindita L, Vijaya L. Chapter two review of relevant studies, goal achievement. Singh. Chapter two review of relevant studies, goal achievement. Satisfaction Satisfaction and happiness. 2005.

35. Arslan C, Ceviz D. Evaluation of obesity prevalence and health promoting life-style profiles of housewives and working women. Journal of Health Sciences of Firat University 2007;21:211-20.

36. Mufti WN, Ullah IA, Fatima S. Aggression, self-control and quality of life among working and non-working women. European Journal of Business and Social Sciences 2015;4:132-40.

37. Bhattacharya S, Ganguli A. Attitude towards money, materialistic value and quality of life-a study on working and non-working women. Indian Journal of Psychological Science 2016;6:18-22.

38. Mukerji I, Sharma A. Quality of life among working couples and non-working couples. Indian Journal of Health and Wellbeing 2018;9:476-8.

39. Rusli BN, Edimansyah BA, Naing L. Working conditions, selfperceived stress, anxiety, depression and quality of life: a structural equation modelling approach. BMC Public Health 2008;8:48. 